ISHS Acta Horticulturae 1020: VI International Cherry Symposium

\title{
QUALITY OF 'SWEETHEART' CHERRY UNDER DIFFERENT STORAGE CONDITIONS
}

Authors: A.C. Agulheiro Santos, V. Palma, A.E. Rato, G. Machado, M. Lozano, D. González- Gómez

Acta

Horticulturae

Home

Login

Logout

Status

Help

ISHS Home

ISHS Contact

Consultation statistics

index

Search
Keywords: sweet cherry, fruit quality, cold storage, controlled atmosphere, sensory evaluation

\section{Abstract:}

In Portalegre, Portugal, sweet cherry production is very important to the region's economic sustainability. The sweet cherry 'Sweetheart' has exhibited short shelf life in spite of being highly appreciated by consumers due to its organoleptic characteristics. In this trial, we evaluated fruit quality of 'Sweetheart' stored under different storage conditions: 1) cold conditions $\left(1^{\circ} \mathrm{C}\right.$ and high humidity $\left.\left.95 \%\right), 2\right)$ cold conditions and polypropylene film bags (MA), and 3 ) controlled atmosphere (CA) $\left(1^{\circ} \mathrm{C}, 95 \%\right.$ humidity, $10 \% \mathrm{CO}_{2}$ and $8 \% \mathrm{O}_{2}$ ). Fruit physical and chemical parameters were evaluated after 0,6 , 13,20 and 27 days of cold storage. Quality parameters tested included weight loss, external colour $\left(L^{*} a^{*} b^{*}\right)$, visual assessment of the epidermis, epidermis and mesocarp penetration test, soluble solids content (SSC), and titratable acidity (TA). We also performed sensory analyses. The results for textural properties, colour coordinates and sensory analysis suggest that 'Sweetheart' fruit can be stored under cold conditions, $1^{\circ} \mathrm{C}, 95 \%$ humidity, for up to 21 days without significant loss of quality. Controlled atmosphere maintained tissue turgidity during storage; however, this was not noticed by the panelists, who consistently classified fruits stored under CA conditions with lower overall ratings than fruits under cold conditions with or without film bags.

- Full Text (PDF format, 237322 bytes)

- Citation

- Translate

Select Language $\quad \mathbf{\nabla}$
Pow ered by Google Translate

Download Adobe Acrobat Reader (free software to read PDF files)

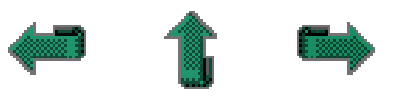

